\title{
Energy Efficiency of Modernization of Translucent Building Envelope Structures
}

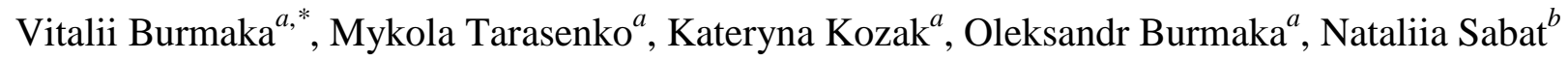 \\ ${ }^{a}$ Ternopil Ivan Puluj National Technical University, Ternopil, 46001, Ukraine \\ ${ }^{b}$ Ivano-Frankivsk National Technical University of Oil and Gas, Ivano-Frankivsk, 76019, Ukraine
}

Received: July 06, 2021. Revised: November 05, 2021. Accepted: November 12, 2021.

() 2021 The Authors. Published by Lviv Polytechnic National University.

\begin{abstract}
The article focuses on determining the energy efficiency of the translucent structures of building envelope (TSBE) use with different lighting and thermal parameters. The expediency of replacing TSBE with more modern ones with higher thermal resistance and lower solar radiations relative penetration coefficient (SRRPC) is considered. The comparison was made taking into account the influence of TSBE parameters on electricity consumption in the office premises on the compensation of heat energy losses, as well as its savings due to the receipt of solar radiation during the heating period, the removal of excess heat during the cooling period and energy savings through the use of daylight during a year. It was found that despite the smaller glazing area and light-transmitting characteristics of configuration No. 3 (profile Veka Softline 82 with triple-glazed window 4Solar-16Ar-4-12Ar-4i), electricity savings when changing the configuration of TSBE No. 1 to No. 3 leads to energy savings of $31.7 \mathrm{kWh} / \mathrm{yr}$ with the TSBE area of $0.5 \mathrm{~m}^{2}$ to $419.5 \mathrm{kWh} / \mathrm{yr}$ at $6 \mathrm{~m}^{2}$, and when replacing configuration No2 by No3 - from $24.7\left(S_{\mathrm{TSBE}}=0.5 \mathrm{~m}^{2}\right)$ up to $397.2\left(S_{\mathrm{TSBE}}=6 \mathrm{~m}^{2}\right)$. This makes it possible to determine the energy and economic feasibility of TSBE modernization by installing metal-plastic structures with different lighting and thermal parameters.
\end{abstract}

Keywords: TSBE; windows energy efficiency; composite index of glazing rooms; energy efficiency of daylighting.

\section{Introduction}

The lighting industry consumes about 2650 TWh of electricity per year ( $\approx 19 \%$ of global production) exclusively for lighting, exceeding its total production by all nuclear power plants in the world [1]. According to the State Inspectorate for Energy Supervision of Ukraine, the cost of electricity for artificial lighting in the integrated energy system of Ukraine is about 2.4 million $\mathrm{kWh}$ (10-12\% of total electricity consumption) [2]. At the same time, it is possible to almost half electricity costs without deteriorating lighting conditions by improving the means and methods of lighting, reconstruction of existing lighting installations and the organization of its proper operation [3].

Despite the significant improvement in the energy consumption characteristics of devices and energy saving of buildings, an important aspect of energy efficiency is the use of renewable energy sources. In the case of the lighting industry, it is the use of daylight. The simplest design for daylighting is TSBE. Despite its important functional role, in terms of daylight, the parameters that affect its effectiveness are insufficient studied.

\section{Formulation of the problem}

Despite a significant amount of research in the daylightings field, the issue of energy efficiency of TSBE replacement with modern ones, taking into account not only thermal parameters, but also lighting parameters, is not sufficiently disclosed. This determines the study relevance of changes in the total energy balance of the room depending on the type of profile and TSBE glazing.

\footnotetext{
${ }^{*}$ Corresponding author. Email address: vitaliy.burmaka@gmail.com
}

This paper should be cited as: V. Burmaka, M. Tarasenko, K. Kozak, O. Burmaka, N. Sabat. Energy efficiency of modernization of translucent building envelope structures. Energy Engineering and Control Systems, 2021, Vol. 7, No. 2, pp. 87 - 96. https://doi.org/10.23939/jeecs2021.02.087 
The study purpose is to determine the impact on the energy balance of the premises of different types of translucent external enclosing structures and to establish the energy efficiency of their replacement with modern ones.

\section{Analysis of recent research and publications}

Research on TSBE energy efficiency was conducted not only by Ukrainian researchers, such as: Martynov V.L. [3], [4], Halinska T.A. [5]-[8], Kolesnyk Y.S. [9], [10], Sopilniak A.M. [11], as well as foreign: Jennifer L. [12], Ghisi E. and Tinker J. [13], [14] etc.

In particular, Martinov V.L. in [3], [4] described a computerized way to optimize the orientation of energyefficient face-shaped buildings (taking into account the geometric shape of the building, area and location of windows) by minimizing the thermal balance of building envelopes with the environment during the heating period with observance of norms of illumination and insolation.

The studies of Mason M et al. [15], [16] described a methodology of estimations for more precise calculation of heat flow through the windows and provide visual comfort to the occupants. They obtained the appropriate formulas based on data used by industry in glass manufacturing technologies. As a result, some empirical adjustment factors have been introduced and are publicly available at the Center of Glass.

Regulatory and legal framework analysis, existing buildings, approaches to the energy efficiency of buildings during the design, construction, reconstruction and operation, developed recommendations for improving the quality and resource efficiency of buildings by ensuring their energy efficiency conducted in [17]. In particular, the authors point out that houses can be designed to capture the low-altitude rays of the winter sun to heat and use window protection to block high altitudes in the summer sun. The aim is not to get the maximum possible amount of solar energy at any cost, but to keep the minimum energy demand for heating to a minimum [18].

The research [19] highlights the problem of improving energy efficiency in the construction industry. The comparison of heat transfer indices for building envelope (BE) of Ukraine and those close to the climatic conditions of Finland was carried out. In the study [20] authors cite the main trends in improving the design of modern windows. The regulatory requirements for the production of modern energy efficient windows have been studied. Prospects for the introduction of innovative energy efficient window systems are revealed.

In [21]-[25] the results of experimental research into a heat transfer of various double-glazed windows and window profiles are given. For this purpose, an experimental measuring complex was created to study the thermal insulation properties of the building's TSBE. The authors first experimentally discovered the thermophysical effect, which is to reverse the direction of heat flow on the outer surface of the glass and window profile, which is associated with the non-stationary heat transfer process and the influence of daytime scattered solar radiation. As a result, the optimal type of double-glazed windows and the distance between the panes, which can be recommended for installation in a window opening and for use in passive type houses, have been determined.

The article [26] analyzed the influence of the installation of different types of windows on the thermal energy condition of a mass building for different window to wall ratios (WWR) using dynamic grid models created on the basis of the software product EnergyPlus. For northern and southern orientations, energy consumption was determined and analyzed when heating a building with energy-saving windows with selective spraying and/or filling the chambers with inert gas, the transmission characteristics of solar heat supply which meet and expand the limits of current standards in Ukraine. The influence of changes in environmental parameters during the heating period on the indicators of thermal comfort and the average radiation temperature for different TSBE glazing configurations was studied. The range of changes in the average radiation temperature and room temperature for the heating period is estimated. Recommendations were given for regulating changes in indoor air temperature to ensure the appropriate category of the building for comfortable conditions.

\section{Methodology}

The amount of saved electricity due to the TSBE use was determined by equation (1)

$$
W_{\mathrm{TSBE}}=S_{\mathrm{R}} \times p_{\mathrm{AL}} \times D A_{300}-\left(\omega_{\mathrm{H}}-Q_{\mathrm{H}}\right) / C O P-Q_{\mathrm{C}}^{\mathrm{MAX}} / E R R, \mathrm{kWh} / \mathrm{yr},
$$

where $S_{\mathrm{R}}$ is room's floor area, $\mathrm{m}^{2} ; p_{\mathrm{AL}}$ is specific power of artificial lighting, $\mathrm{kWh} / \mathrm{m}^{2} ; D A_{300}$ is daylight autonomy (at illumination in $300 \mathrm{~lx}$ ), h/yr; $\omega_{\mathrm{H}}$ is thermal energy losses in the heating period, $\mathrm{kWh} / \mathrm{yr} ; Q_{\mathrm{H}}$ is solar radiation gaining 
through the TSBE during the heating period $\mathrm{kWh} / \mathrm{yr} ; C O P$ is coefficient of performance $(\mathrm{kW} / \mathrm{kW}) ; Q_{\mathrm{C}}{ }^{\mathrm{MAX}}$ is the highest value of heat solar radiation gaining into the working space through the TSBE glazing during the cooling period $\mathrm{kWh} / \mathrm{yr}$; EER is energy efficiency ratio $(\mathrm{kW} / \mathrm{kW})$.

Since the daylight factor (DF) is influenced by the location of window openings in the BE in order to compare window openings of different shapes and areas, their centers must be at one point W (Fig. 1).

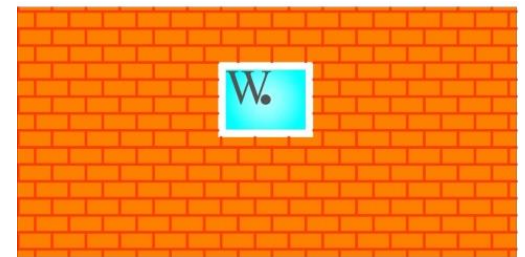

a)

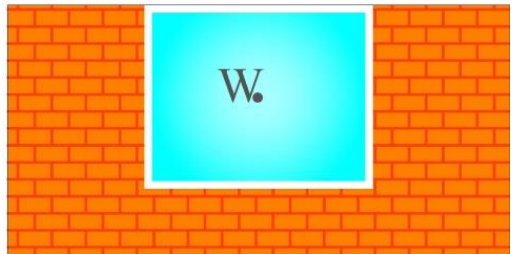

b)

Fig.1. Appearance of a fencing structure with a rectangular TSBE area a) $1 \mathrm{~m}^{2}$; b) $6 \mathrm{~m}^{2}$.

The thickness of foaming $\left(l_{\mathrm{FF}}\right)$ was determined by the algorithm presented in [27].

Daylight autonomy (DA) can be defined in specialized software Relux, for any location. According to [28], for arbitrary sizes of premises and the TSBE area, in Ternopil, $D A_{300}$ was determined by equation (2) with a standard deviation of 82.6 and a determination coefficient of 0.979

$$
D A_{300}=-0.227 \cdot I_{\mathrm{GL} . \mathrm{R}}^{2}+45.854 \cdot I_{\mathrm{GL} . \mathrm{R}}-420.953, \mathrm{~h} / \mathrm{yr},
$$

where $I_{\mathrm{GL} . \mathrm{R}}$ is composite room glazing index (CRGI) [29], \%.

According to [28], [29] the composite room glazing index (CRGI) is defined by the equation

$$
I_{\mathrm{GL} . \mathrm{R}}=S_{\mathrm{GL}} / S_{\mathrm{WS}} \cdot \sqrt[l_{\mathrm{wP}}]{2 \cdot l_{\mathrm{WP}} / d_{\mathrm{WP}}} \cdot 100, \%
$$

where $S_{\mathrm{GL}}$ is TSBE glazing area, $\mathrm{m}^{2}$ [28]; $S_{\mathrm{WS}}$ is working surface area $\left(S_{\mathrm{WS}}=2 \times l_{\mathrm{WP}} \times d_{\mathrm{WP}}\right), \mathrm{m}^{2} ; d_{\mathrm{WP}}, l_{\mathrm{WP}}$ are the coordinates of the working point (WP) location in the room (Fig. 2), m.

Based on these data, as well as the dependence of the CRGI on DF (3), according to [29] it is possible to determine the required TSBE glazing area.

Thermal energy losses were defined as the difference between losses due to TSBE and losses due to the same area of BE. Heat losses due to TSBE, $\mathrm{kWh} / \mathrm{yr}$ with the option of regular heating during non-working hours, according to SNiP II-4-79, are determined by the equation (4)

$$
\omega_{\mathrm{H}}=\left(\begin{array}{l}
10^{-3} \cdot 1.1 \cdot(1.3+\eta) \cdot\left(1 / R_{\mathrm{TSBE}}-1 / R_{\mathrm{R}}\right) \cdot z_{\mathrm{H}} \cdot S_{\mathrm{TSBE}} \times \\
\times\left[\left(t-t_{\mathrm{AV} . \text { OUTD }}\right) \cdot T+\left(t_{\mathrm{ST}}-t_{\mathrm{AV} . \text { OUTD }}\right) \cdot(8760-T)\right]
\end{array}\right) / 365, \mathrm{kWh} / \mathrm{yr},
$$

where 1.1 is the coefficient, which takes into account heat losses in heating systems [30], rel. units.; 1.3 is the coefficient which takes into account heat losses on heating the external air entering through TSBE [30], rel. units; $\eta$ is the coefficient which takes into account the additional heat losses through the BE [31, Append. 5, Table 2] (Table 1), rel. units; $R_{\mathrm{TSBE}}$ is thermal resistance of TSBE, $\left(\mathrm{m}^{2} \times{ }^{\circ} \mathrm{C}\right) / \mathrm{W} ; R_{\mathrm{R}}$ is prescribed by the regulations $\mathrm{BE}$ thermal resistance value [32], $\left(\mathrm{m}^{2} \times{ }^{\circ} \mathrm{C}\right) / \mathrm{W} ; t_{\mathrm{AV} \text {.ouTd }}$ is average outdoor temperature for the heating period (DSTU B EN 15251), ${ }^{\circ} \mathrm{C} ; t$ is the estimated winter air temperature indoors during working hours [31], ${ }^{\circ} \mathrm{C} ; T$ is annual working hours, taken in 2150 hours when working in one shift, 4300 hours when working in two shifts, 6500 hours when working in three shifts, $\mathrm{h} /$ year; $S_{\mathrm{TSBE}}$ is TSBE area in ceiling or BE, $\mathrm{m}^{2} ; z_{\mathrm{HP}}$ is the duration of the heating period for residential premises (DSTU-N B V.1.1-27 2010), days; $t_{\mathrm{ST}}$ is the temperature inside the room, in standby heating mode [33], ${ }^{\circ} \mathrm{C}$.

For calculation of the thermal insulation of TSBE properties and radiation heat inputs through their transparent part, it is necessary to know what TSBE part is taken up by glazing (glass), profile and foaming. These results were obtained as a result of the calculation performed by the algorithm described in [27]. 


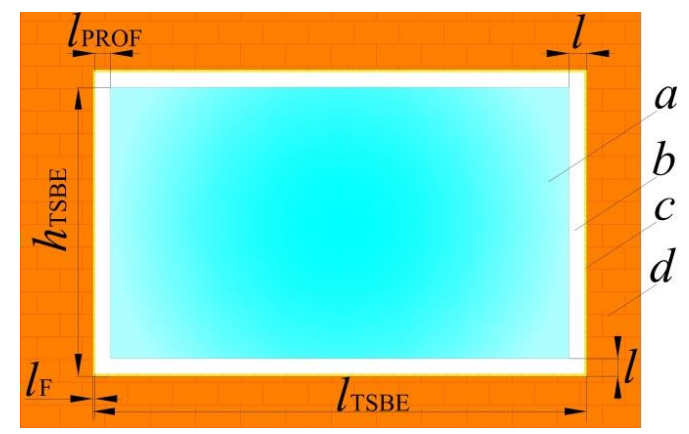

Fig. 2. Schematic representation of a rectangular TSBE: a) glazing b) profile; c) foaming; d) building envelope [34].

Three TSBE configurations were chosen for calculations: No. 1 - wooden profile with double glazing (Fig. 3a) [35]; No. 2 - profile Veka PROLINE [36] with double-glazed window 4-16-4 (Fig. 3b) [37]; No. 3 - profile Veka Softline 82 [38] with triple-glazed window 4Solar-16Ar-4-12Ar-4i (Fig. 3c) [39].

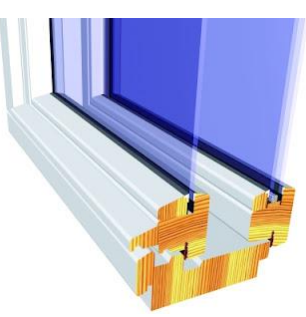

a)

wooden profile (No.1)

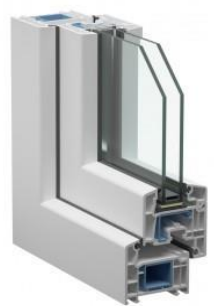

b)

profile Veka PROLINE (No.2)

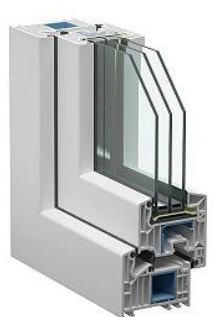

c)

profile Veka Softline 82 (No.3)

Fig. 3. Selected window profiles.

The parameters of the selected profile, double-glazed windows and foaming (foam) are given in Table 1.

Table 1. Selected profiles, glazing and foaming parameters [35]-[39].

\begin{tabular}{|l|c|}
\hline \multicolumn{1}{|c|}{ Name } & Thermal resistance, $\left(\mathrm{m}^{2} \times \mathrm{C}\right) / \mathrm{W}$ \\
\hline \hline Paired wooden profile & 0.44 \\
\hline Profile glass & 0.31 \\
\hline Profile Veka PROLINE & 0.8 \\
\hline Profile Veka Softline 82 & 1.06 \\
\hline Double-glazed window 4-16-4 & 0.32 \\
\hline Triple-glazed window 4Solar-16Ar-4-12Ar-4i & 1.14 \\
\hline Foam Ceresit TS 62 & 2.73 \\
\hline
\end{tabular}

The inflow of solar radiation through the TSBE during the heating period $\left(Q_{\mathrm{H}}\right)$, for the facades of the house, oriented in four directions - south $(\mathrm{S})$, north $(\mathrm{N})$, west $(\mathrm{W})$ and east $(\mathrm{E})$, were determined, according to [36], by the equation (5)

$$
Q_{\mathrm{H}}=\varepsilon_{\mathrm{GL}} \cdot\left(S_{\mathrm{GL} . \mathrm{S}} \cdot I_{\mathrm{S}}+S_{\mathrm{GL} . \mathrm{N}} \cdot I_{\mathrm{N}}+S_{\mathrm{GL} . \mathrm{W}} \cdot I_{\mathrm{W}}+S_{\mathrm{GL} . \mathrm{E}} \cdot I_{\mathrm{E}}\right), \mathrm{kWh} / \mathrm{yr},
$$

where $S_{\mathrm{GL} . S}, S_{\mathrm{GL} . \mathrm{N}}, S_{\mathrm{GL} . \mathrm{W}}, S_{\mathrm{GL} . \mathrm{E}}$ are the area of glazing in the facade of the building, oriented to the south, north, west and east, respectively, $\mathrm{m}^{2} ; I_{\mathrm{S}}, I_{\mathrm{N}}, I_{\mathrm{W}}, I_{\mathrm{E}}$ are the average value of solar radiation during the heating period, directed to the vertical surface under cloudy conditions, oriented to the south, north, west and east, respectively [36, Table 2], $\mathrm{kWh} / \mathrm{m}^{2}$.

The maximum value of solar radiation heat input to the working area during the cooling period is determined by the maximum value of the total solar radiation that enters the TSBE surface during the day and is calculated, according to [30], by equation

$$
Q_{\mathrm{C}}^{\mathrm{MAX}}=\left(Q_{\mathrm{DIR} . \mathrm{R} . \mathrm{VII}}^{\mathrm{MAX}}+Q_{\mathrm{DIF} . \mathrm{M} . \mathrm{VII}}^{\mathrm{MAC}}\right) \cdot \varepsilon_{\mathrm{GL}} \cdot \tau_{2} \cdot \tau_{3} \cdot \tau_{4} \cdot \bar{s}_{\mathrm{GL}} \cdot S_{\mathrm{TSBE}} \cdot T_{\mathrm{C}} \cdot 10^{-3}, \mathrm{kWh} / \mathrm{yr},
$$

where $Q_{\text {DIR.R.VII }}^{\mathrm{MAX}}$ is the highest value of direct solar radiation in July at the time of a cloudless sky on a vertical surface by a certain orientation [32], W/m²; $Q_{\text {DIF.R.VII }}^{M A X}$ is the highest value of diffuse solar radiation in July in the cloudless sky 
on the vertical surface of a certain orientation (DSTU-N B V.1.1-27 2010), W/m $\mathrm{m}^{2} ; \tau_{2}$ is coefficient that takes into account the light loss in the opaque covers (window profile) TSBE [41], rel. un.; $\tau_{3}$ is coefficient that takes into account the decreasing of heat gains due to a glass pollution [31, Append. 12, Table 5], rel. un.; $\tau_{4}$ is coefficient of heat transmission of shading devices, rel. un. [41]; $T_{\mathrm{C}}$ is duration of the cooling system work during cooling period [40], h/yr.

According to [43], the average COP value for modern ducted air conditioners is 3.41 , and the EER is 2.73 . Thermal resistance for the first temperature zone of Ukraine is $R_{\mathrm{R}}=3.3 \mathrm{~m}^{2} \times{ }^{\circ} \mathrm{C} / \mathrm{W}$. Equations for determining the energy savings by using of the TSBE, for the Ternopil city, according to [42]:

- South orientation

$$
W_{\mathrm{TSBE}}=S_{\mathrm{R}} \cdot p_{\mathrm{AL}} \cdot D A_{300}-S_{\mathrm{TSBE} . \mathrm{S}} \cdot\left(\left(34.097 / R_{\mathrm{TSBE}}-10.333\right)-19.74 \cdot \bar{s}_{\mathrm{GL}} \cdot \varepsilon_{\mathrm{GL}}\right), \mathrm{kWh} / \mathrm{yr}
$$

- North orientation

$$
W_{\mathrm{TSBE}}=S_{\mathrm{R}} \cdot p_{\mathrm{AL}} \cdot D A_{300}-S_{\mathrm{TSBE} . \mathrm{S}} \cdot\left(\left(36.720 / R_{\mathrm{TSBE}}-11.127\right)-12.18 \cdot \bar{s}_{\mathrm{GL}} \cdot \varepsilon_{\mathrm{GL}}\right), \mathrm{kWh} / \mathrm{yr} ;
$$

- West orientation

$$
W_{\mathrm{TSBE}}=S_{\mathrm{R}} \cdot p_{\mathrm{AR}} \cdot D A_{300}-S_{\mathrm{TSBE} . \mathrm{W}} \cdot\left(\left(35.409 / R_{\mathrm{TSBE}}-10.730\right)+26.12 \cdot \bar{s}_{\mathrm{GL}} \cdot \varepsilon_{\mathrm{GL}}\right), \mathrm{kWh} / \mathrm{yr} ;
$$

- East orientation

$$
W_{\mathrm{TSBE}}=S_{\mathrm{E}} \cdot p_{\mathrm{AL}} \cdot D A_{300}-S_{\mathrm{TSBE} . \mathrm{E}} \cdot\left(\left(36.720 / R_{\mathrm{TSBE}}-11.127\right)+27.12 \cdot \bar{s}_{\mathrm{GL}} \cdot \varepsilon_{\mathrm{GL}}\right), \mathrm{kWh} / \mathrm{yr} .
$$

\section{Results of the research}

The dependence of heat loss on the value TSBE thermal resistance was carried out according to the method presented in [44]. Premises whose parameters meet the requirements of current regulations of Ukraine were analyzed [32], [44], [45].

Currently, a large number of free, high-precision programs for daylighting calculating have been developed. Calculations of the daylight autonomy (DA) were performed in the Relux program, the reliability of which was tested experimentally in [46], [47]. The calculations were performed according to the algorithm given in [28]. Calculations were performed for a room with dimensions (width $\times$ depth $\times$ height) $6 \times 5 \times 3 \mathrm{~m}$.

As a result, the dependence of the annual $D A_{300}$ (for prescribed by regulators illumination of $3001 \mathrm{x}$ ) for the Ternopil city was obtained (Fig. 4).

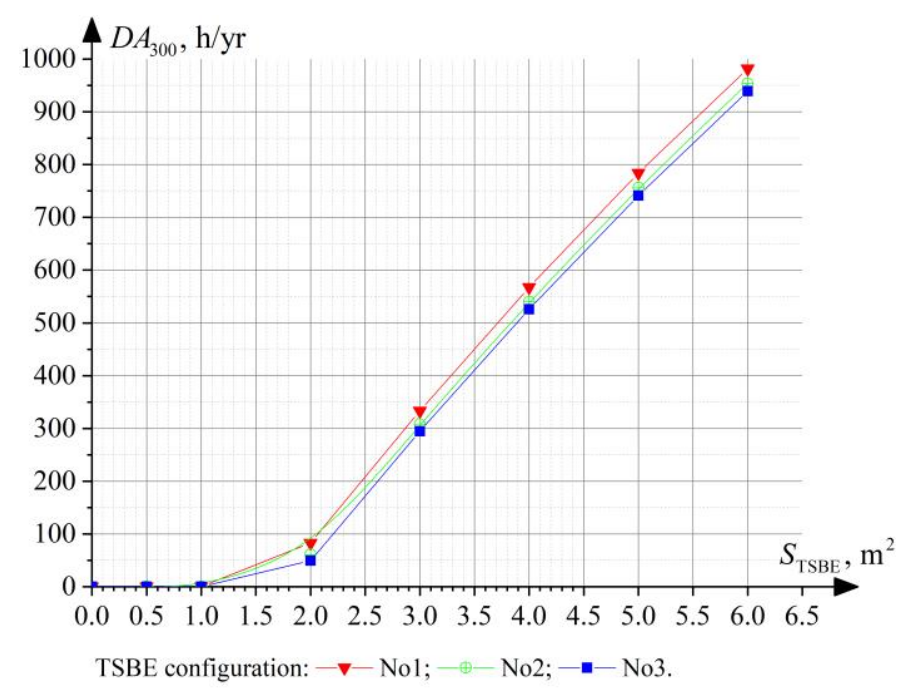

Fig. 4. Total annual $D A_{300}$ at the reference point, $\mathrm{h} / \mathrm{yr}$.

As can be seen from Fig. 4, the largest $D A_{300}$ value is provided by TSBE with the largest SRRPC (configuration No.1). For the TSBE configuration No.2, with the TSBE area of $6 \mathrm{~m}^{2}$, the $D A_{300}$ value is $1.6 \%$ higher than in the configuration No.3. For the TSBE configuration No.1, with the TSBE area of $6 \mathrm{~m}^{2}$, the $D A_{300}$ value is $2.9 \%$ higher than in the configuration No. 2 and $5 \%$ higher than in the configuration No.3. 
The integrated thermal resistance calculation results for the rectangular metal-plastic windows mounted in the slot of the main bearing opaque TSBE of different area, at the coordination index equal to 1, are given in Table 4 .

Table 4. Integral thermal resistance $\left(R_{\mathrm{TSBE}}\right)$ of different area TSBE with different types of windows glazing, profiles, $\left(\mathrm{m}^{2} \times \mathrm{C}\right) / \mathrm{W}$.

\begin{tabular}{|c|c|c|c|c|c|c|c|}
\hline \multirow{2}{*}{ TSBE option } & \multicolumn{5}{|c|}{ TSBE area, $\mathrm{m}^{2}$} \\
\cline { 2 - 7 } & 0.5 & 1 & 2 & 3 & 4 & 0 \\
\hline \hline No.1 & 0.355 & 0.341 & 0.332 & 0.329 & 0.327 & 0.325 \\
\hline No.2 & 0.424 & 0.384 & 0.365 & 0.357 & 0.352 & 0.349 & 0.347 \\
\hline No.3 & 1.147 & 1.145 & 1.144 & 1.145 & 1.145 & 1.146 & 1.146 \\
\hline
\end{tabular}

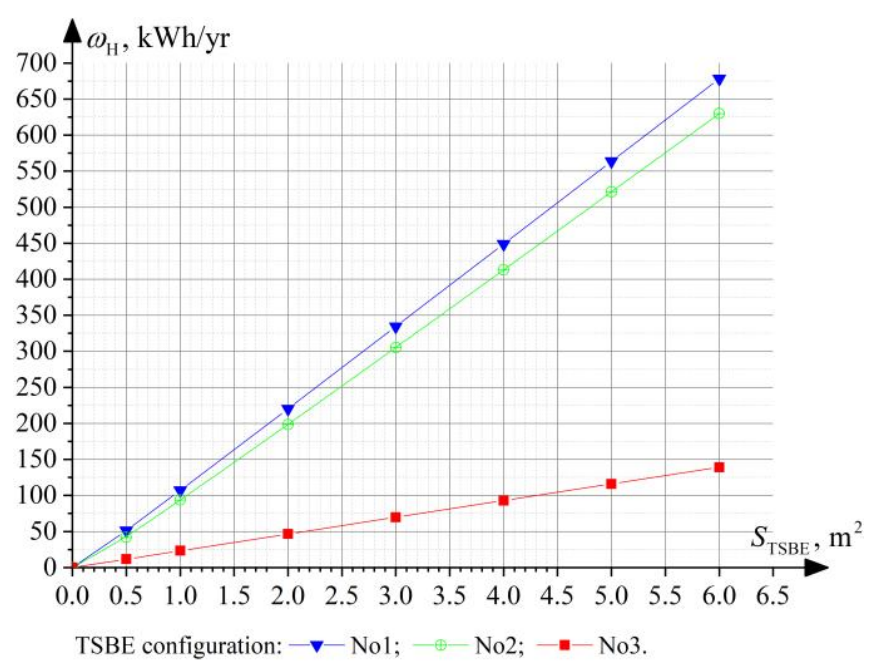

Fig. 5. Heat losses during the heating period $\left(\omega_{\mathrm{H}}\right)$ for the climatic zone I (Ternopil city), $\mathrm{kWh} / \mathrm{yr}$

The heating system operating temperature, according to [31], is $20^{\circ} \mathrm{C}$. The cooling system operating temperature is $26^{\circ} \mathrm{C}$. All calculations were performed for the Ternopil city $\left(49^{\circ} 34^{\prime} \mathrm{N} 25^{\circ} 36^{\prime} \mathrm{E}\right)$. The results of electricity consumption for heating calculations are shown in Fig. 5.

As can be seen from Fig. 5, the largest losses of thermal energy are observed in the TSBE configuration No.1. For the TSBE configuration No.2, with the TSBE area of $6 \mathrm{~m}^{2}$, heat losses during the heating period are lower by $7.2 \%$, than with the configuration No.1. For the TSBE configuration No.3, with the TSBE area of $6 \mathrm{~m}^{2}$, heat losses during the heating period are lower by $77.9 \%$, than with the configuration No.2 and by $79.5 \%$ than with No.2.

The results of the solar radiation receipts calculation through the TSBE during the heating period, when changing the TSBE area for its various configurations, are shown in Fig. 6.

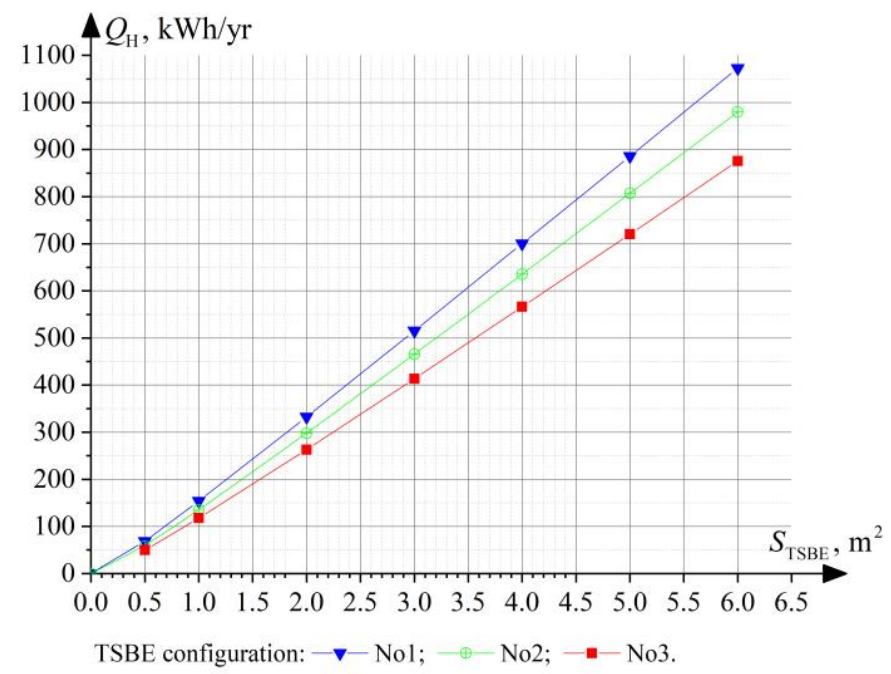

Fig. 6. The solar radiation flow through TSBE during the heating period dependence on the TSBE area for different TSBE configurations, for Ternopil city. 
As can be seen from Fig. 6, the largest inflows of thermal energy during the heating period are observed at TSBE with the configuration No.1. For the TSBE configuration No.2, with the TSBE area of $6 \mathrm{~m}^{2}$, the heat input during the heating period is greater by $9.5 \%$, than with the configuration No.2. For the TSBE configuration No.1, with $6 \mathrm{~m}^{2}$ area, the value is greater by $11.9 \%$ than with the configuration No.2 and by $22.5 \%$ than with No.3.

The maximum value of radiation heat input to the working area during the cooling period results of calculating for the Ternopil city are shown in Fig. 7.

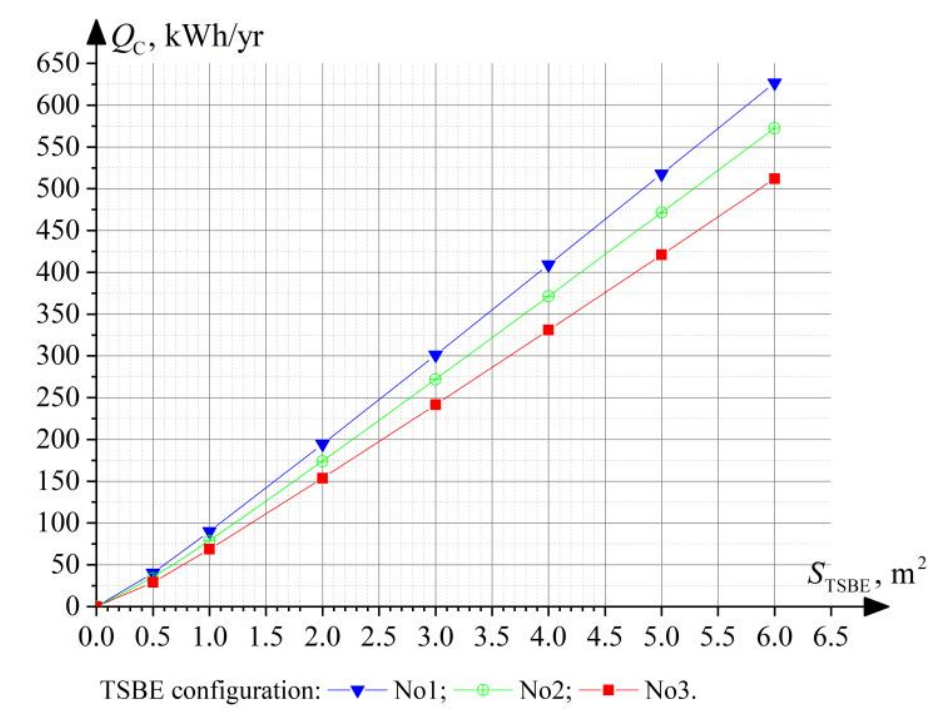

Fig. 7. The maximum value of radiation heat inputs through TSBE during the cooling period dependence on the TSBE area for the Ternopil city.

In terms of penetration of solar thermal energy TSBE configurations differ in the SRRPC values and the glazing area. That's why, in percentage terms, the difference in excess heat during the cooling period between them is the same as the heat during the heating. However, in absolute units, the values differ. Thus, when using TSBE with configuration No.2, excess heat is less than in No.1 by $54.274 \mathrm{kWh} / \mathrm{yr}$, with No.3 by $60.662 \mathrm{kWh} / \mathrm{yr}$ than in No.2 and by $114.936 \mathrm{kWh} / \mathrm{yr}$ than in No.1. Revenues during the heating period with configuration No.2 are lower by 92.880 kWh/yr, and in No.3 are lower by 103.811 than with No.2 and by 196.691 less in No.1. That is, as we see from Fig. 6 and Fig. 7 receipts during the heating period are greater than excess heat receipts during the cooling period.

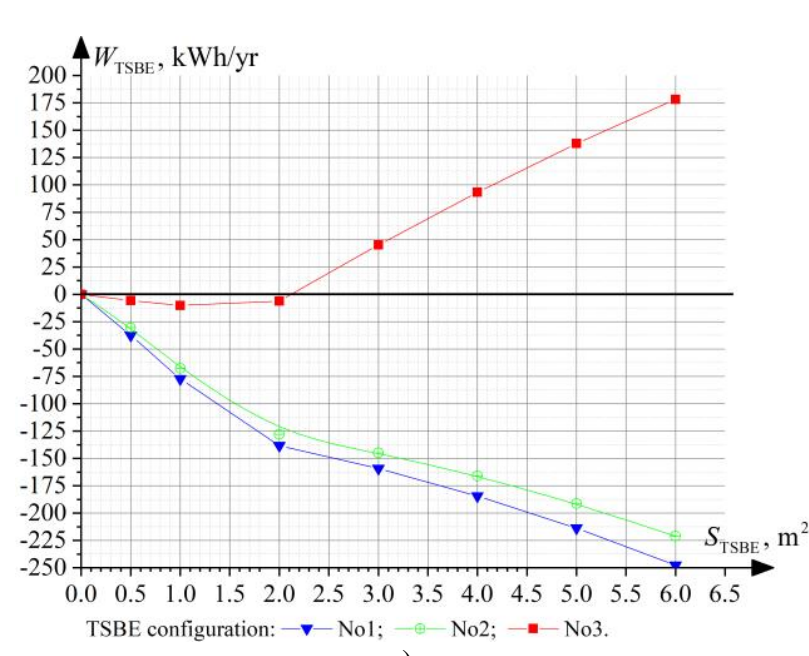

a)

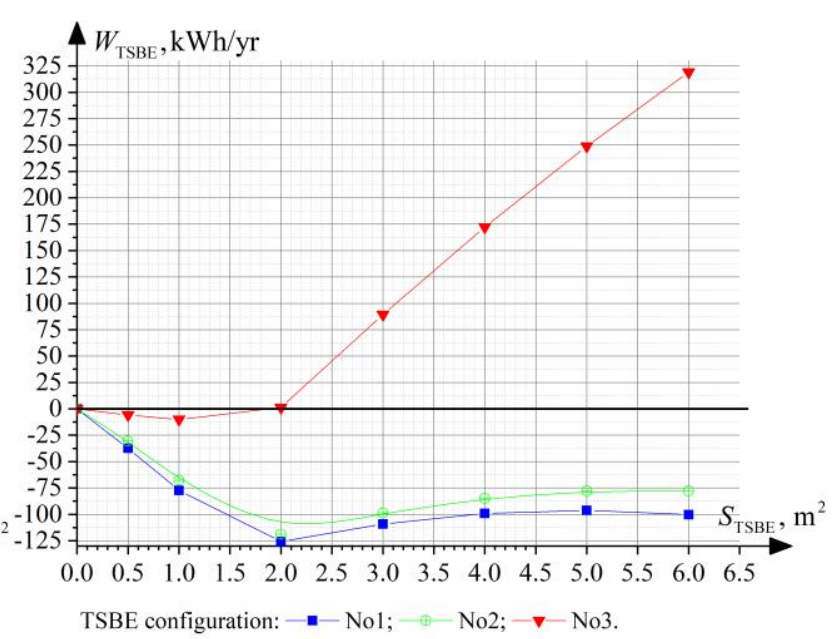

b)

Fig. 8. Energy savings due to the TSBE use at the specific power of the artificial lighting: a) $8 \mathrm{~W} / \mathrm{m}^{2}$; b) $13 \mathrm{~W} / \mathrm{m}^{2}$.

Modern HVAC cooling devices use two parameters to assess energy efficiency: coefficient of performance $(C O P)$ and energy efficiency ratio $(E E R) . C O P$ is the ratio of the declared power for heating the air to the nominal 
power input for space heating, which provides heating under standard test conditions. EER is the ratio of the cooling capacity to the power input under standard test conditions. These two parameters are not the same. According to [43], the average COP value for Neoclima duct air conditioners [48] is $3.41 \mathrm{~kW} / \mathrm{kW}$, and the average EER value is 2.73 $\mathrm{kW} / \mathrm{kW}$. That is, the electricity consumed to remove $1 \mathrm{kWh}$ of heat energy during the cooling period is by $25 \%$ greater than to compensate of $1 \mathrm{kWh}$ of heat loss during the heating period.

According to [41, p. 22], the maximum specific power of artificial lighting to provide illumination of $300 \mathrm{~lx}$, depending on the index of the room ranges from 8 to $13 \mathrm{~W} / \mathrm{m}^{2}$. Therefore, we consider options with these two values of the specific power of the artificial lighting system to compare the energy efficiency of TSBE replacement (Fig. 8).

As can be seen from Fig. 8, the use of modern TSBE (No.3) with an area of more than $2 \mathrm{~m}^{2}$ allows reducing the total electricity consumption in the room to ensure prescribed by regulators climatic requirements. While the use of TSBE with configurations No.1 and No.2 leads to an increase in total electricity consumption.

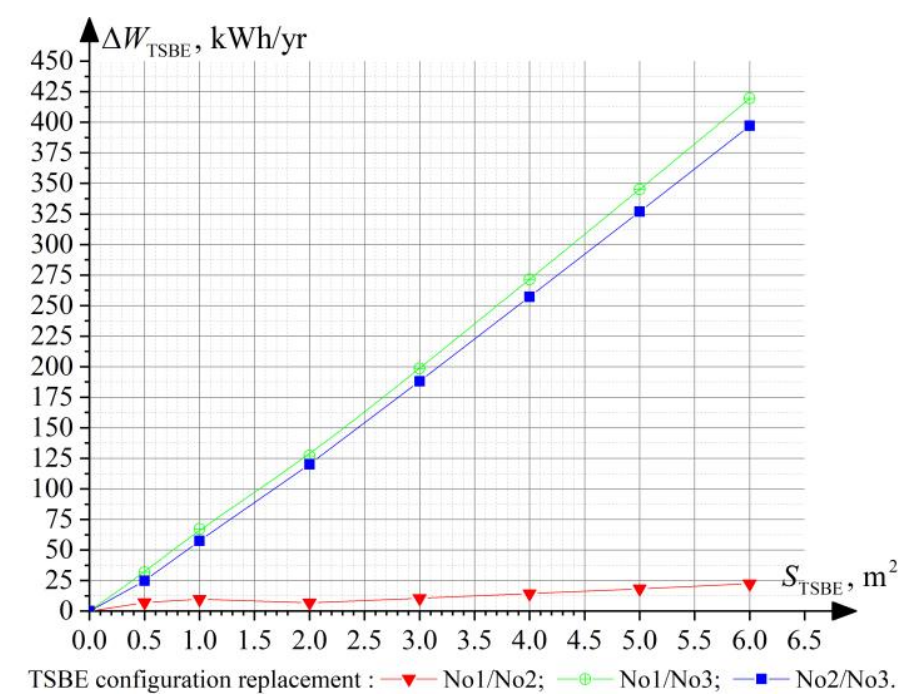

Fig. 9. Dependence of electricity savings due to the TSBE configuration replacement No.1 by No.2, No.1 by No.3 and No.2 by No.3 on the TSBE area.

Since daylight is a mandatory factor in terms of compliance with regulatory requirements and ensuring standardized sanitary and hygienic indicators, TSBE must be available in the premises for various purposes.

To determine the feasibility of modernizing TSBE by replacing them with more modern ones, consider the energy efficiency of TSBE replacement $\left(\Delta W_{\text {TSBE }}\right.$ ) with the configuration No.1 by No.2 and No.3 and, No.2 by No.3, which is defined as the difference between energy consumption at the corresponding TSBE configurations (Fig. 9).

As can be seen from Fig. 9, the TSBE modernization with configurations No1 and No2 by No3 allows reducing electricity consumption by 2.898 times and 2.604 times, respectively. While changing the TSBE configuration No1 to No2 leads to a decrease in electricity consumption only by 1.103 times.

\section{Conclusion}

Despite the slight improvement of the thermal insulation characteristics of the Veka PROLINE profile with double glazing 4-16-4 in comparison with the paired wooden profile with double glazing, their energy efficiency is almost the same. From the energy saving point of view, there is no sense in replacing the TSBE configuration No.1 by No.2, as the reduction in electricity consumption is 1.103 times with the TSBE area of $6 \mathrm{~m}^{2}$, and when the area is reduced it will be reducing as well.

Although the TSBE configuration No.3 has a smaller relative glazing area and worse light transmission characteristics than the configuration No.1, replacing the latter with No.3 leads to energy savings, from 31.699 $\mathrm{kWh} / \mathrm{yr}$ at the TSBE area of $0.5 \mathrm{~m}^{2}$ to $419.508 \mathrm{kWh} / \mathrm{yr}$ at $6 \mathrm{~m}^{2}$. Replacement of the configuration No.2 by No.3 leads to energy savings, from 24.731 at $0.5 \mathrm{~m}^{2}$ to 397.146 at the TSBE area of $6 \mathrm{~m}^{2}$. According to the presented data, TSBE modernization with the use of modern profile and triple-glazed windows allows not only reducing electricity consumption, but also eliminating heat loss during the heating period and its excess during the cooling period by reducing the duration of artificial lighting and heat gains during the heating period. 
The replacement of obsolete TSBE with both wooden and metal-plastic profile with low thermal resistance to modern leads to significant energy savings and the larger TSBE area leads to the greater energy savings, which is why research in this area is relevant and requires more detailed study of the parameters that affect the TSBE energy-saving properties.

\section{References}

[1] Tarasenko M., Kozak K., Burmaka V. (2015). Dynamic of parameters of high-pressure discharge lamp at building-up and dimming. Lighting Engineering \& Power Engineering, 3-4, 15-21. (in Ukrainian).

[2] Chernenko P.O., Martyniuk O.V. (2012). Enhancing the effectiveness of short-term forecasting of electric load of united power system. Tekhnichna Elektrodynamika, 1, 63-70. (in Ukrainian).

[3] Martynov V.L (2013). Optimization of geometrical parameters of the form, light apertures and a heater of energy-efficient buildings, Building constructions. Theory and practice, 77, 317-322. (in Ukrainian).

[4] Martynov V.L (2013). Determination of optimal orientation of energy efficient buildings in accordance with standards of illumination and insolation, Visnyk Kremenchutskoho natsionalnoho universytetu imeni Mykhaila Ostrohradskoho, 5, 173-176. (in Ukrainian).

[5] Galinska T.A., Nosach B.L., Leshchenko M.V., Likhtei V.V. (2013). Experimental studies of the thermal properties of translucent enclosing building envelope. Construction, materials science, mechanical engineering, 68, 104-108. (in Ukrainian).

[6] Leshchenko, M.V., Galinska, T.A., Reznikov, A.A. (2013). Researching of wall cladding structure heat endurance in civil buildings during their thermo modernization, Collection of scientific works. Series: Industrial engineering, construction, 4(2), 114-121. (in Ukrainian).

[7] Yurin, O., Galinska, T. (2017). Study of heat shielding qualities of brick wall angle with additional insulation located on the outside fences, MATEC Web Conf, 116, 02039. https://doi.org/10.1051/matecconf/201711602039

[8] Yurin, O., Azizova, A., Galinska, T. (2018). Study of heat shielding qualities of a brick wall corner with additional insulation on the brick, MATEC Web Conf, 230, 02039. https://doi.org/10.1051/matecconf/201823002039

[9] Belous, O.M., Kolesnyk, Y.S. (2011). Structural considerations of energy efficiency of translucent enclosing structures, Modern industrial and civil construction, 7(4), 243-250. (in Ukrainian).

[10] Kolesnyk, Y.S. (2011). Providing of energy efficiency in civilian buildings with light slit facades, Modern technology, materials and design in construction, 1, 148-154. (in Ukrainian).

[11] Sopilnyak, A.M. (2017). Improving thermal protection of translucent enclosing structure, Construction, materials science, mechanical engineering, 98, 161-165. (in Ukrainian).

[12] Jennifer, L., Williamson, P.E., Fu, T., Gabby, B., Testa, J., Hu Ch. (2018). Glazing in commercial buildings - the balance between cost and energy consumption, Building performance analysis conference and simbuild co-organized by ASHRAE and IBPSA-USA Chicago, IL September 26-28, 221-228.

[13] Ghisi, E., Tinker, J.A. (2001). Optimising energy consumption in offices as a function of window area and room size, Seventh International IBPSA Conference Rio de Janeiro, Brazil August 13-15, 1307-1314.

[14] Ghisi, E., Tinker, J.A. (2004). Window sizes required for the energy efficiency of a building against window sizes required for view, CIB World Building Congress at: Toronto, Canada, 1-12.

[15] Mason M., Airah, L., Kingston, T., Airah, M. (2010). Why determining thermal loads through windows is such a pane - Part 1, EcoLibrium, 34-40.

[16] Mason M., Airah, L., Kingston, T., Airah, M. (2010). Why determining thermal loads through windows is such a pane - Part 2, EcoLibrium, 30-36.

[17] Lapa M. Dvoieglazova M. Pechonkin I. Lapa Yu. (2017). Providing of buildings energoefficiency, Technical Sciences and Technologies, 1(7), 225233. (in Ukrainian).

[18] Indigo shire council. URL: http://www.indigoshire.vic.gov.au.

[19] Serdyuk V., Serdyuk T., Franyshina S. (2019). Improvement of external fencing structures as a source of heat loss in building. Modern technology, materials and design in construction, 26(1), 153-159. (in Ukrainian). https://doi.org/10.31649/2311-1429-2019-1-153-159 (in Ukrainian).

[20] Serdyuk V., Honcharyk A. (2018). Trends in the use of modern windows for residential buildings, Innovative technologies in construction -2018, 1315 November2018, 4 p. (in Ukrainian).

[21] Basok B. I., Nakorchevskii A. I., Goncharuk S. M., Kuzhel' L.N. (2017). Experimental investigations of heat transfer through multiple glass units with account for the action of exterior factors, Journal of engineering physics and thermophysics, 90(1), 94-101.

[22] Basok B., Davydenko B., Zhelykh V., Goncharuk S., Kugel L. (2016). Influence of low-emissivity coating on heat transfer through the doubleglazing windows. Building physics in theory and practice, Scientific Journal, 8(4), 5-8.

[23] Basok B.I., Davydenko B.V., Isaev S.A., Goncharuk S.M., Kuzhel' L.N. (2016). Numerical modeling of heat transfer through a triple-pane window, Journal of engineering physics and thermophysics, 89(5), 1288-1295.

[24] Lysenko O.M. Kuzhel L.M. Bozhko I.K. (2015). Control of heat supply of building based on the use of individual heat point of original design, Eastern-European Journal of Enterprise Technologies, 1(8(73), 61-67. https://doi.org/10.15587/1729-4061.2015.37917

[25] Kuzhel L.M. (2017). Regularities of heat transfer through window constructions, Doctoral dissertation, Kyiv 190 p. (in Ukrainian).

[26] Deshko V.I., Buiak N.A., Bilous I.Yu., Hurieiev M.V., Holubenko O.O. (2018). Assessment of the influence of vacuum replacement on energy consumption and conditions of comfort in building on the basis of dynamic modeling, Power engineering: economics, technique, ecology, 3, 52-62. https://doi.org/10.20535/1813-5420.3.2018.164428

[27] Tarasenko M., Burmaka V., Kozak K. (2018). Dependences of relative and absolute glazed area from configuration and common areas of window embrasure, Scientific Journal of TNTU, 89(1), 122-131. https://doi.org/10.33108/visnyk_tntu2018.01.122

[28] Burmaka V., Tarasenko M., Kozak K., Omeiza L.A., Sabat N. (2020). Effective use of daylight in office rooms, Journal of Daylighting, 7(2), 154166. https://dx.doi.org/10.15627/jd.2020.15

[29] Burmaka V., Tarasenko M, Kozak K, Khomyshyn V. (2018). Definition of a composite index of glazing rooms, Eastern-European Journal of Enterprise Technologies, 4(10 (94)), 22-28. https://doi.org/10.15587/1729-4061.2018.141018

[30] A guide to the calculation and design of natural, artificial and combined lighting (to SNiP II-4-79). M.: Strojizdat, 1980, 156 p. (in Russian) 
[31] Building regulations. Part II «Design standards. Chapter 33 «Heating, ventilation and air conditioning»: SNiP II-33-75. M.: Strojizdat, 1976, 109 p. (in Russian).

[32] Thermal insulation of buildings: DBN V.2.6-31:2016. K.: Ministry of Regional Development of Ukraine, 2017, 31 p. (in Ukrainian).

[33] Engineering encyclopedia. URL: http://engineeringsystems.ru/d/dejurnoe-otoplenie.php. (in Russian).

[34] Burmaka V.O. Improving the energy efficiency of combined lighting of buildings taking into account the energy balance of the premises. $\mathrm{PhD}$ thesis, Ternopil Ivan Puluj National Technical University, Ternopil, 2020, 190 p. (in Ukrainian).

[35] Wooden windows for industrial buildings. Types, design and dimensions: GOST 12506-81. Moscow: Publishing house of standards. 1987, 18 p. (in Ukrainian).

[36] Profile Proline, (n.d.) URL: http://veka.ua. Proline. Profile system for professional solutions in the window business. (in Ukrainian).

[37] Guidelines for the development and compilation of an energy passport of buildings for new construction and reconstruction: DSTU-N B A.2.25.2007. K.: Ministry of Regional Development and Construction of Ukraine, 2008. (in Ukrainian)

[38] Profile Softline 82, (n.d.) URL: http://veka.ua. SOFTLINE 82. An innovative energy efficient system that meets the high demands of the future. (in Ukrainian)

[39] Viknaroff. Master of window work (n.d.). URL: https://viknaroff.com. - Single-chamber and double-chamber double-glazed windows. (in Ukrainian)

[40] Ceresit (n.d.) URL: http://www.ceresit.ua. TS 62 mounting foam professional universal. (in Ukrainian)

[41] Daylighting and artificial lighting: DBN V.2.5-282018. K.: Ministry of Regional Development of Ukraine, 2018, 113 p. (in Ukrainian)

[42] Liubarets O.P. (2018). Calculation parameters for cooling period in Ukraine. Heating, Ventilation and Air Conditioning in Buildings, 24, 11-16. (in Ukrainian).

[43] Burmaka V., Tarasenko M., Kozak K., Khomyshyn V. (2019). Impact of the translucent structures of exterior wall envelope orientation on the energy balance of the premises, Scientific Journal of TNTU, 94(2), 111-122. https://doi.org/10.33108/visnyk_tntu2019.02.111

[44] Burmaka V., Tarasenko M., Kozak K., Sabat N., Khomyshyn V., Yuskiv V. (2020). Conditions for ensuring energy-saving use of translucent structures of exterior wall envelope. Energy Engineering and Control Systems, 6(2), 71-80. https://doi.org/10.23939/jeecs2020.02.071

[45] Construction of buildings and structures. Windows and doors. General specification: DSTU B V.2.6-23:2009. Kyiv: Ministry of Regional Development of Ukraine, 2009, 32 p. (in Ukrainian)

[46] Makarov D.N., Computer simulation methods for lighting installations, Doctoral dissertation, Moscow Power Engineering Institute 2007. URL: http://lightonline.ru/documents/Other/Dissertation_MakarovDN.html (in Russian)

[47] Yu, Xu, Su, Y., Chen, X. (2014). Application of RELUX simulation to investigate energy saving potential from daylighting in a new educational building in UK, Energy and Buildings, 74, 191-202. http://dx.doi.org/10.1016/j.enbuild.2014.01.024

[48] Neoclima (n.d.). URL: http://neoclima.ua. Catalogue. (in Russian)

\title{
Енергоефективність модернізації світлопрозорих зовнішніх огороджувальних конструкцій
}

\author{
Віталій Бурмака $^{a}$, Микола Тарасенко ${ }^{a}$, Катерина Козак $^{a}$, Олександр Бурмака ${ }^{a}$, Наталія Сабат $^{b}$ \\ ${ }^{a}$ Тернопільський начіональний технічний університет імені Івана Пулюя, Тернопіль, 46001, Украйна \\ ${ }^{b}$ Івано-Франківський національний технічний університет нафти і газу, Івано-Франківськ, 76019, Украӥна
}

\section{Анотація}

Стаття присвячена визначенню енергоефективності використання світлопрозорих зовнішніх огороджувальних конструкцій (СЗОК) з різними світлотехнічними та теплотехнічними параметрами. Також розглянуто доцільність заміни СЗОК на сучасніші з більшим термічним опором та меншим коефіцієнтом відносного проникнення сонячної радіації (КВПСР). Порівняння проведено при врахуванні впливу параметрів СЗОК на споживання електроенергії в офісному приміщенні на компенсацію втрат теплової енергії, а також іiі економію за рахунок надходження сонячного випромінювання протягом опалювального періоду, видаленням надлишкового тепла протягом охолоджувального періоду та економію електроенергії за рахунок використання денного світла. Встановлено, що попри меншу площу засклення і світлопропускаючі характеристики варіанту №3 (профіль Veka Softline 82 з склопакетом 4Solar-16Ar-4-12Ar-4i), економія при заміні конфігурації СЗОК №1 на №3 призводить до економії енергії від 31.7 (кВт×год)/рік при площі СЗОК

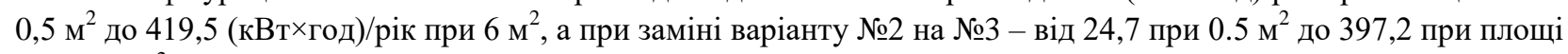

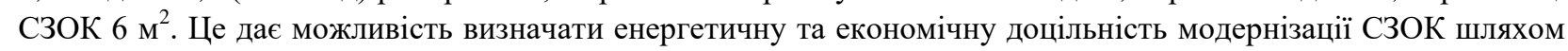
встановлення метало пластикових конструкцій з різними світлотехнічними та теплотехнічними параметрами.

Ключові слова: СЗОК; енергоефективність вікон; зведений індекс засклення приміщення; енергоефективність природного освітлення. 